\title{
PROJETO PRÁTICAS PÚBLICAS E POBREZA
}

Práticas Públicas e Pobreza é um projeto do Programa Gestão Pública e Cidadania. Criado em 1998, está direcionado para a pesquisa aplicada e a divulgação de práticas e conhecimentos sobre a temática específica da pobreza e a participação de diferenciados atores sociais no seu enfrentamento. Com isto pretendeu-se contribuir com o debate nacional sobre soluções concretas e alternativas voltadas à melhoria da qualidade de vida e à inclusão social das populações pobres. Apoiado inicialmente pela Fundação Ford, conta hoje também com o apoio da Fundação Hewlett. O Projeto Práticas Públicas e Pobreza não tem por objetivo quantificar a pobreza e a população empobrecida do Brasil. Trata-se de uma iniciativa que visa construir e sistematizar um conhecimento prático a partir da análise de micropolíticas sociais que vêm apresentando, no cotidiano, resultados concretos em termos de valorização e ampliação de direitos, inserção social e fortalecimento da capacidade de intervenção local.

Nesse trabalho, assim como no Programa Gestão Pública e Cidadania, há importantes lições a serem aprendidas, desde ações simples e aparentemente óbvias, até aquelas que articulam recursos dos mais variados tipos por meio de novos arranjos institucionais. Na maioria das experiências, as organizações estatais trabalham em parceria, ora com outras organizações do mesmo setor, ora com organizações privadas e da sociedade civil. Saberes populares e tradicionais se juntam a conhecimentos técnicos e a idéias práticas derivadas de outras experiências. O resultado é uma vasta escola ou colégio invisível de possibilidades de ação.

\section{Principais atividades do projeto}

1. Realização de estudos e pesquisas focalizando, nas suas diversas formas, as práticas sociais e públicas emergentes, que vêm demonstrando ter um impacto direto na qualidade de vida e na inclusão social das populações empobrecidas.

2. Promoção de seminários temáticos nacionais, regionais e internacionais, envolvendo atores oriundos de diferentes segmentos de ação e reflexão: das comunidades, da academia, de organizações da sociedade civil e da área pública. 
3. Promoção de cursos e de oficinas itinerantes em avaliação de políticas públicas e de capacitação em gestão social para profissionais de prefeituras municipais, governos estaduais, instituições de desenvolvimento, organizações não-governamentais e comunidades em geral.

4. Produzir material escrito e audiovisual para fins de disseminação de práticas e conhecimentos, como também para uso didático. 